\title{
Effects of Aerobic Exercise on Bone-Specific Alkaline Phosphatase and Urinary CTX Levels in Premenopausal Women
}

\section{Premenopozal Kadınlarda Aerobik Egzersizin Kemik Spesifik Alkalen Fosfataz ve Üriner CTX Üzerindeki Etkileri}

\author{
Alev ALP \\ Uludağ University Faculty of Medicine, Department of Physical Therapy and Rehabilitation, Bursa, Turkey
}

\begin{abstract}
Summary
Objective: This study aimed to investigate the effects of moderate-intensity aerobic exercise on bone turnover by urinary cross-linked C-telopeptide of type I collagen (CTX) and serum bone-spesific alkaline phosphatase (BAP) in comparison with a control group.

Materials and Methods: 100 premenopausal volunteers from our outpatient unit were randomized into 2 equal groups. The exercise group $(n=50)$ performed the exercise sessions supervised by a physiotherapist for $40 \mathrm{~min}$ a day, 5 times a week for a duration of 2 months. The control group $(n=50)$ maintained their sedentary lifestyle for the duration. Urinary CTX and BAP levels in the subjects were measured before and at the end of the intervention. Results: The changes in CTX and BAP from baseline were statistically significant in the exercise group for but not in the control group. When the groups were compared with each other, the exercise group was found to be superior to the control group for the change in CTX.

Conclusion: Two months of regular submaximal aerobic exercise decreased bone resorption rate in premenopausal sedentary women.

Key Words: Aerobic exercise, bone-spesific alkaline phosphatase, cross linked c telopeptide of type 1 collagen.
\end{abstract}

Özet

Amaç: Orta şiddette aerobik egzersizin üriner tip I kollajen karboksi terminal çapraz bağ telopeptid (Ctx) ve serum kemik spesifik alkalen fosfataz (BAP) üzerindeki etkileri araştıııldı.

Gereç ve Yöntem: Polikliniğimize başvuran 100 gönüllü sedanter premenopozal kadın iki eşit gruba randomize edildi. Egzersiz grubu $(n=50)$ günde $40 \mathrm{dk}$, haftada $5 \mathrm{kez}$ ve 2 ay boyunca fizyoterapist eşliğinde toplu egzersiz yaptı. Kontrol grubu $(n=50)$, sedanter yaşam şeklini devam ettirdi. Üriner Ctx ve serum BAP, çalışmanın başında ve sonunda olmak üzere iki kez değerlendirildi.

Bulgular: Ctx ve BAP da başlangıçtan bu yana olan değişimler, sadece egzersiz grubunda istatistiksel olarak anlamlı bulundu. Kontrol grubuyla karşılaştırıldığında, egzersiz grubu sadece Ctx seviyelerindeki değişim bakımından kontrol grubuna üstün bulundu.

Sonuç: İki ay düzenli yapılan submaksimal aerobik egzersizin, premenopozal sedanter kadınlarda kemik rezorpsiyonunu azalttığı gözlendi.

Anahtar Sözcükler: Aerobik egzersiz, kemik spesifik alkalen fosfataz, tip I kollajen karboksi terminal çapraz bağ telopeptid

\section{Introduction}

Bone is a dynamic tissue that is able to adapt its structure and strength to mechanical loading environment and it has been suggested that weight-bearing exercise increases bone density and prevents or reduces postmenopausal or agerelated bone loss $(1,2)$. Based on current understanding of the pathology of osteoporosis and its modification by physical activity, generally accepted strategies to improve bone health and to reduce the incidence of osteoporotic fractures in women aim to: maximize peak bone mass during growth (childhood and adolescence), minimize age-related bone loss (middle-aged adults/premenopausal women) and prevent falls and fractures (in older adults/postmenopausal women) (3). The efficacy of mechanical loading as a potent osteogenic influence on bone is a well-known issue in bone health research, but there is still a wide gap between research and practice in terms of using physical activity as an effective and inexpensive means of preventing osteoporosis $(3,4)$. Given that $15 \%$ to $25 \%$ of bone mineral density (BMD) can be lost during the premenopausal years alone, if prevention of osteoporosis is not properly addressed in this at-risk population, considerable social and health care costs will continually be directed towards treatment and this will be an economically undesirable outcome $(5,6)$.

Different findings have emerged from previous systematic reviews and meta-analyses evaluating the optimal type and

Address for Correspondence/Yazışma Adresi: Alev Alp MD, Uludağ University Faculty of Medicine, Department of Physical Therapy and Rehabilitation, Bursa, Turkey Phone: +902242347691 E-mail: dr.alevalp@hotmail.com 
amount of exercise intervention that can significantly alter bone turnover and remodeling in premenopausal women and impact exercises (aerobic and weight-bearing exercises) have put forth consistent positive results (7-9). High-impact activities are most effective in improving femoral neck BMD at the hip, a common site of osteoporotic fracture (10). However, the dose response, the optimal amount, intensity, frequency, and duration of exercise are less known, because of difficulties in long-term evaluation of the effects of exercise in populationbased studies (11).

Weight-bearing stimulus can be produced by both resistance exercises and aerobic exercises. It has been reported that forces greater than those experienced in daily living activities are required for improving bone mass (12).

Dual energy $\mathrm{x}$-ray absorptiometry (DEXA) is used to quantify BMD and to diagnose osteoporosis or osteopenia, however, it has little value for monitoring the efficacy of a medical or exercise therapy in a few months. For this purpose, bone turnover markers are helpful in clinical practice. Biochemical markers of bone remodeling, a dynamic process of breakdown and renewal of bone in order to maintain mechanical integrity of skeleton, provide a dynamic measurement of skeletal status (13). Resorption markers fall in 2-12 weeks while formation markers act a little bit slower (3-6 months). When there is a change in the remodeling process, formation markers such as alkaline phosphatase or resorption markers like collagen cross-links can be measured in blood or urine as a reflection of the bone turnover. Serum cross-linked C-telopeptide of type I collagen (CTX) is a marker of osteoclast activity and is used to assess the level of bone resorption (14). Bone specific alkaline phosphatase (BAP) levels reflect the osteoblastic activity and the bone mineralization process. This study aimed to investigate the effects of moderate-intensity aerobic exercise on bone turnover by urinary CTX and serum BAP in comparison with a control group and to determine whether additive weight-bearing physical activity would cause observable changes in bone metabolism.

\section{Materials and Methods}

\section{Patients}

The study population consisted of 100 sedentary premenopausal women who volunteered to participate in the study from the outpatient unit of our department. Data collected from the subjects included age, body weight and height (BMI), detailed medical history for systemic illness or medication, menopause and physical activity levels. Physical activity level for each subject was determined to be 'sedentary' according to her lifestyle as 'office worker or housewife getting little or no exercise' or functionally as 'walking less than 1.5 $\mathrm{km} /$ day or standing $4 \mathrm{hrs} /$ day (16-18).

We excluded subjects with metabolic bone-related diseases (e.g., primary hyperparathyroidism, kidney dysfunction requiring chronic hemodialysis, thyroid dysfunction, osteomalacia, etc.), other systemic diseases (e.g., infectious diseases, rheumatic disorders or malignancy) or those who were participating in an exercise group. Before starting the intervention, the hospital ethics committee approval and the patients' written informed consent were obtained.

\section{Randomization}

100 subjects were randomized into 2 equal groups. Simple randomization was performed using a computer-generated table of random numbers. No stratification or blocking was done during the randomization procedure.

\section{Intervention}

The exercise group $(n=50)$ performed the exercise sessions under the supervision of a physiotherapist for 40 min a day, 5 times a week for a duration of 2 months. The aerobic exercise program consisted of warming (5 minutes), stretching (5 minutes), step aerobics (20 minutes), cooling (5 minutes) and stretching (5 minutes) sections. Blood pressures and radial pulses of the subjects were checked before and after the therapy. Intensity of aerobic exercise in this study was defined in terms of the Borg Scale $(17,18)$ and in the intervention group was adjusted to a submaximal level 12-14, matching the targeted heart rate for submaximal aerobic exercise as $60-85 \%$ of Heart Rate Maximum (220-age) $(2,18,19)$. Borg's rating of perceived exertion (RPE) is a widely used psycho-physical tool to assess subjective perception of effort during exercise. RPE between 12-14 at the Borg Scale suggests physical activity is being performed at a Borg Scale level of 'somewhat hard' or 'moderate level of intensity' matching the submaximal level of aerobic exercise. The patients were warned of the cardiac symptoms; chest pain, dizziness and dyspnea as well as abnormal lumbar pain during the exercise program and were advised to stop and notify the supervisor. The subjects in the control group $(n=50)$ were instructed to maintain their sedentary lifestyle for the duration.

Blood and urinary samples were taken once from each patient before and at the end of the intervention between 8:00 and 10:00 a.m. after a 12-hr fast.

Biochemical Analysis

Urinary CTX was measured by Osteosal kit and expressed as T-scores. CrossLaps measured by Osteosal is a bone resorption marker found on the C-telopeptide of type 1 collagen. Serum alkaline phosphatase (IU/L) and BAP levels (range: 0-20\%l) were measured by C16000 Abbott Architect System. BAP rate (\%) was changed to IU/L manually according to total alkaline phosphatase levels.

Statistical Analysis

Statistical analysis was done by SPSS version 11.5 for Windows. The groups were evaluated by the KolmogorovSmirnov test if they were or were not normally distributed for all of the variables. Since the variables in both groups were normally distributed, student-t test was used to determine whether any differences existed among the initial mean values in the groups for the variables; age and body mass index (BMI) (Table 1). Changes from baseline values for each group (within comparisons) were evaluated using a paired samples t-test for normally distributed variables (Table 2 ).

Comparison of the groups as change scores were done by student's t-test (Table 3). Statistical analysis was done according to the intention to treat principle.

\section{Results}

100 voluntary female subjects were enrolled in this study and randomized into exercise $(n=50)$ and control $(n=50)$ 
Table 1. Baseline patient characteristics in the exercise and control groups showed that the groups were homogenous for age and BMI.

\begin{tabular}{llll} 
& $\begin{array}{l}\text { Exercise Group } \\
(\text { mean } \pm \text { SD })\end{array}$ & $\begin{array}{l}\text { Control Group } \\
(\text { mean } \pm \text { SD })\end{array}$ & p-value \\
\hline Age & $47 \pm 7$ & $49 \pm 5$ & 0.54 \\
BMl $\left(\mathrm{kg} / \mathrm{m}^{2}\right)$ & $24.08 \pm 3.45$ & $25.01 \pm 5.33$ & 0.15 \\
\hline
\end{tabular}

BMI: Body Mass Index

\section{Table 2. Changes in CTX and BAP from baseline.}

\begin{tabular}{cllll} 
& & $\begin{array}{c}\text { Baseline } \\
(\text { mean } \pm \text { SD })\end{array}$ & $\begin{array}{c}2^{\text {nd }} \text { month } \\
(\text { mean } \pm \text { SD })\end{array}$ & p-value \\
\hline $\begin{array}{c}\text { CTX } \\
\text { (T-score) })\end{array}$ & Exercise Group & $1.02 \pm 0.97$ & $0.64 \pm 0.57$ & 0.008 \\
& Control Group & $0.97 \pm 0.65$ & $1.13 \pm 0.81$ & 0.421 \\
BAP & Exercise Group & $5.41 \pm 0.92$ & $6.85 \pm 2.36$ & 0.025 \\
(IU/L) & Control Group & $7.44 \pm 2.09$ & $7.18 \pm 1.04$ & 0.173 \\
\hline
\end{tabular}

CTX: Urinary Cross-linked C-telopeptide of Type I Collagen, BAP: Serum Bonespecific Alkaline Phosphatase

Table 3. Comparison of the groups by laboratory variables as
percent changes at the end of the $\mathbf{2}^{\text {nd }}$ month.
\begin{tabular}{llll}
\hline & $\begin{array}{l}\text { Exercise Group } \\
(\text { mean } \pm \text { SD) }\end{array}$ & $\begin{array}{l}\text { Control Group } \\
(\text { mean } \pm \text { SD) }\end{array}$ & p-value \\
\hline CTX (T-score) & $-0.37 \pm 0.02$ & $0.16 \pm 0.12$ & 0.03 \\
BAP (IU/L) & $0.26 \pm 0.19$ & $-0.03 \pm 0.01$ & 0.51 \\
\hline
\end{tabular}

CTX: Urinary Cross-linked C-telopeptide of Type I Collagen, BAP: Serum BoneSpecific Alkaline Phosphatase

groups with the mean age of $47 \pm 7$ and $49 \pm 5$, respectively. In addition, at baseline evaluation, groups were determined to be homogeneous for patient characteristics ( $p>0.05$ ) (Table 1)

All patients completed the program and none of the patients had cardiovascular or other systemic problems. Four subjects in the exercise group missed some (1 to 3 ) of the exercise sessions, but all of the participants were included in the statistical analysis regardless of attendance irregularities.

Changes from baseline were statistically significant in the exercise group for CTX $(p=0.008)$ and BAP $(p=0.025)$. There was no significant change in the control group from baseline (Table 2). When the groups were compared with each other, the exercise group was found to be superior to the control group for the change in CTX $(p=0.03)$ (Table 3$)$.

\section{Discussion}

The strength of aging bone depends on the balance between the resorption and formation phases of the remodeling process. The purpose of this study was to examine the interaction of aerobic exercise training with the potential to exert positive influences on bone turnover. Therefore, this study revealed that 2 months of regular submaximal aerobic exercise decreased bone resorption marker, CTX, in premenopausal sedentary women. CTX concentrations decrease steeply between birth and 25 years but persist in significant amounts throughout adult-life until menopause. Body weight is associated with bone age as an independent variable for CTX and osteocalcin (20). Because both groups in our study were homogeneous for baseline physical characteristics such as age and weight, CTX can be assumed to be unaffected from physical parameters.

Bone resorption markers can decrease or increase daily and CTX has a diurnal rhythm and for its stabilization, 2 months time is needed. BAP is not influenced by the diurnal rhythm and treatment changes become stable at 3-6 months. Nevertheless, unstable changes may occur daily. In our study, when the groups were compared with each other at the end of the $2 \mathrm{nd}$ month, the difference in BAP was not statistically significant, probably because of the short follow-up period.

Disparate findings have emerged from previous systematic reviews and meta-analyses evaluating the optimal type and amount of exercise intervention that can significantly alter bone turnover and remodeling in premenopausal women (10, $21,22)$. In a systematic review of randomized trials by Wallace and Cumming (21), it has been shown that both impact and non-impact exercises have a positive effect at the lumbar spine in pre- and postmenopausal women. Impact exercise probably has a positive effect at the femoral neck. The most important narrative reviews on exercise and bone mass concluded that intervention studies show a positive effect of exercise on bone mass or that intervention studies provide conflicting results (23-28). Gutin and Kasper (29) concluded that in general, bone mass can be enhanced by both strenuous aerobic exercise and strength training. All agree that cross-sectional studies show larger positive effects.

It seems that mild general exercise such as walking is not effective in preventing postmenopausal bone loss or enhancing bone mass in younger age. The way in which exercise is thought to act on the skeleton is through gravitational forces or muscle pull producing strains within the skeleton which are perceived by bone cells as osteogenic. If a strain is detected as greater than the optimum strain, then bone formation will occur (30). Nevertheless, another study revealed that 12 weeks of highintensity resistance training did not appear to enhance bone formation or inhibit bone resorption in young adult women, as assessed by biochemical markers (CTX, BAP, deoxypridinolin) of bone metabolism (31).

Based on a recent meta-analysis, brief high-impact exercise improves BMD at the hip but not at the lumbar spine (32). The individual studies in this review also showed no consistent benefit of this type of exercise on spinal BMD. It has been suggested that the loads engendered during highimpact exercise are hinged upon the interaction between the targeted bone morphology and the amount and orientation of mechanical load applied to it (33). It appears that the mechanical load generated during jumping exercises could have been attenuated before being translated to the spine and it does not generate sufficient osteogenic stimulus for bone formation (34). Moreover, different bone regions may respond differently to mechanical loads due to similar movements (33).

In the Japanese population-based osteoporosis (JPOS) cohort study which revealed the association between biochemical markers of bone turnover and bone loss (determined by BMD measurement. Premenopausal women with elevated levels of resorption and formation markers showed significantly greater bone loss during the follow-up than those with lower levels, after adjustment for the effects of age, body mass index, diet, regular exercise and smoking. The greatest coefficient of determination 
during the first 3 years of follow-up was observed between CTX levels and bone loss at the hip (35). The inverse relationship between the quintile of CTX and mean bone density is consistent in other different and various references (36).

With the foregoing evidence that biochemical markers of bone turnover may predict bone loss, this exercise intervention was planned to reveal the biochemical effect of increase in physical activity by means of moderate-intensity aerobic training in sedentary premenopausal women. In conclusion, our study provides clear evidence that bone resorption rate measured by CTX can be altered by aerobic exercise in a 2 months period. Our limitation is the inadequate follow-up period to determine the change in the bone formation marker; BAP, because of the reason that formation can take three to six months until the new bone structural unit is fully formed. Therefore, further studies on the physiologic effects of exercise training on bone metabolism and bone quality to prevent or treat bone loss are needed with a longer follow-up period.

\section{Conflict of Interest}

Authors reported no conflicts of interest.

\section{References}

1. Chow R, Harrison JE, Notarius C. Effect of two randomised exercise programmes on bone mass of healthy postmenopausal women. $\mathrm{Br}$ Med J (Clin Res Ed) 1987;295:1441-4.

2. Zhang J, Feldblum PJ, Fortney JA. Moderate physical activity and bone density among perimenopausal women. Am J Public Health 1992;82:736-8.

3. Kohrt WM, Bloomfield SA, Little KD, Nelson ME, Yingling VR; American College of Sports Medicine. American College of Sports Medicine Position Stand: physical activity and bone health. Med Sci Sports Exerc 2004;36:1985-96.

4. Hardman AE, Stensel DJ. Physical activity and health: the evidence explained. Taylor Francis Ltd, London, 2009.

5. Dolan SH, Williams DP, Ainsworth BE, Shaw JM. Development and reproducibility of the bone loading history questionnaire. Med Sci Sports Exerc 2006;38:1121-31.

6. National Osteoporosis Society. Key facts and figures, 2010.

7. World Health Organization Global health risks report: mortality and burden of disease attributable to selected major risks. WHO, Genova, 2009.

8. Wallace BA, Cumming RG. Systematic review of randomized trials of the effect of exercise on bone mass in pre- and postmenopausal women. Calcif Tissue Int 2000;67:10-8.

9. Kelley GA, Kelley KS. Efficacy of resistance exercise on lumbar spine and femoral neck bone mineral density in premenopausal women: a meta-analysis of individual patient data. J Womens Health (Larchmt) 2004; 13:293-300.

10. Wolff I, van Croonenborg JJ, Kemper HC, Kostense PJ, Twisk JW. The effect of exercise training programs on bone mass: a meta-analysis of published controlled trials in pre- and postmenopausal women. Osteoporos Int 1999;9:1-12.

11. Jämsä T, Ahola R, Korpelainen R. Measurement of osteogenic exercise - how to interpret accelerometric data? Front Physiol 2011;2:73.

12. Layne JE, Nelson ME. The effects of progressive resistance training on bone density: a review. Med Sci Sports Exerc 1999;31:25-30.

13. Looker AC, Bauer DC, Chesnut CH 3rd, Gundberg CM, Hochberg MC, Klee G, et al. Clinical use of biochemical markers of bone remodeling: current status and future directions. Osteoporosis Int 2000;11:467-80.

14. Lee CY, Suzuki JB. CTX biochemical marker of bone metabolism. Is it a reliable predictor of bisphosphonate-associated osteonecrosis of the jaws after surgery? Part II: a prospective clinical study. Implant Dent 2010;19:29-38.

15. Leeming DJ, Alexandersen P, Karsdal MA, Qvist P, Schaller S, Tankó LB. An update on biomarkers of bone turnover and their utility in biomedical research and clinical practice. Eur J Clin Pharmacol 2006;62:781-92.

16. No authors listed. Human energy requirements: report of a joint FAO/ WHO/UNU Expert Consultation. Food Nutr Bull 2005;29:166.

17. Sinaki M, Grubbs NC. Back strengthening exercises: quantitative evaluation of their efficacy for women aged 40 to 65 years. Arch Phys Med Rehabil 1989;70:16-20.

18. Ay A, Yurtkuran M. Influence of aquatic and weight-bearing exercises on quantitative ultrasound variables in postmenopausal women. Am J Phys Med Rehabil 2005;84:52-61.

19. Larson EB, Bruce RA. Health benefits of exercise in an aging society. Arch Intern Med 1987; 147:353-6.

20. da Silva CC, Kurokawa CS, Nga HS, Moretto MR, Dalmas JC, Goldberg TB. Bone metabolism biomarkers, body weight, and bone age in healthy Brazilian male adolescents. J Pediatr Endocrinol Metab 2012;25:479-84.

21. Wallace BA, Cumming RG. Systematic review of randomized trials of the effect of exercise on bone mass in pre- and postmenopausal women. Calcif Tissue Int 2000;67:10-8.

22. Kelley GA, Kelley KS. Efficacy of resistance exercise on lumbar spine and femoral neck bone mineral density in premenopausal women: a meta-analysis of individual patient data. J Womens Health (Larchmt) 2004;13:293-300.

23. Chilibeck PD, Sale DG, Webber CE. Exercise and bone mineral density. Sports Med 1995; 19:103-22.

24. Mosekilde L. Osteoporosis and exercise. Bone 1995;17:193-5.

25. Smith EL, Gilligan C. Physical activity effects on bone metabolism. Calcif Tissue Int 1991;49:50-4.

26. Snow CM, Shaw JM, Matkin CC. Physical activity and risk for osteoporosis. In: Marcus R, Feldman D, Kelsey ], editors. Osteoporosis. San Diego: Academic Press; 1996. p. 511-28.

27. Bouxsein ML, Marcus R. Overview of exercise and bone mass. Rheum Dis Clin North Am 1994;20:787-802.

28. Marcus R, Drinkwater B, Dalsky G, Dufek J, Raab D, Slemenda C, et al. Osteoporosis and exercise in women. Med Sci Sports Exerc 1992;24(Suppl 6):301-7.

29. Gutin B, Kasper MJ. Can vigorous exercise play a role in osteoporosis prevention? A review. Osteoporos Int 1992;2:55-69.

30. Lanyon LE. Functional strain as a determinant for bone remodeling. Calcif Tissue Int 1984;36:56-61.

31. Mullins NM, Sinning WE. Effects of resistance training and protein supplementation on bone turnover in young adult women. Nutr Metab (Lond) 2005;2:19.

32. Babatunde OO, Forsyth JJ, Gidlow CJ. A meta-analysis of brief highimpact exercises for enhancing bone health in premenopausal women. Osteoporos Int 2012;23:109-19.

33. Vainionpää $A$, Korpelainen $R$, Sievänen $H$, Vihriälä $E$, Leppäluoto J, Jämsä T. Effect of impact exercise and its intensity on bone geometry at weight-bearing tibia and femur. Bone 2007;40:604-11.

34. Coventry E, O'Connor KM, Hart BA, Earl JE, Ebersole KT. The effect of lower extremity fatigue on shock attenuation during single-leg landing. Clin Biomech (Bristol, Avon ) 2006;21:1090-7.

35. Iki M, Morita A, Ikeda Y, Sato Y, Akiba T, Matsumoto T, et al. Biochemical markers of bone turnover predict bone loss in perimenopausal women but not in postmenopausal women-the Japanese Population-based Osteoporosis (JPOS) Cohort Study. Osteoporos Int 2006;17:1086-95.

36. Garnero P, Hausherr E, Chapuy MC, Marcelli C, Grandjean H, Muller $\mathrm{C}$, et al. Markers of bone resorption predict hip fracture in elderly women: the EPIDOS Prospective Study. J Bone Miner Res $1996 ; 11: 1531-8$ 